\title{
Practicing Results Based Management for Enhancement of Quality and Performance of Social Development and Humanitarian Programmes
}

\author{
Khadija Javed Khan ${ }^{1, *}$, Naseem Begum², Abid Razak ${ }^{3}$ \\ ${ }^{1}$ GM Quality Assurance Group, National Disaster Risk Management Fund, Islamabad, Pakistan \\ ${ }^{2}$ Independent Consultant/Oncologist \& Public Health Management, Peshawar, Pakistan \\ ${ }^{3}$ Deputy Manager, M\&E, National Disaster Risk Management Fund, Islamabad, Pakistan
}

Received May 14, 2020; Revised July 8, 2020; Accepted July 20, 2020

Copyright $\mathrm{C} 2020$ by authors, all rights reserved. Authors agree that this article remains permanently open access under the terms of the Creative Commons Attribution License 4.0 International License

\begin{abstract}
The theme of this paper is centred on the application of Results Based Management (RBM) as a tool to achieve high quality management standards and enhance performance. It is originated from the 'Theory of Change' which is pursued globally to reap investment benefits. Whereas the corporate sector utilizes tools like the ISO 9000 series and Total Quality Management (TQM) guidelines, the Not for Profit (NPO) sector has developed its own quality approaches by trial and error. One of the much appreciated methodologies among United Nations (UN) agencies and NPOs is the concept and practice of Results Based Management (RBM). Since its adoption by the UN system in 1997, RBM is known as the 'Gold Standard' among its practitioners. This particular perspective has neither been debated in the Quality Management context nor in RBM literature. However, due to successful and continued adherence to RBM practice by the UN agencies and member states in planning, monitoring and evaluation of development programmes including the Millennium Development Goals (MDGs) and its successor agenda of Sustainable Development Goals (SDGs), it has become imperative to discuss the RBM role in Quality Management. Overall it is partly a description of this extraordinary management concept and practice and partly a fusion of experiences of the authors in the UN agencies and NPO sector.
\end{abstract}

Keywords Quality Management, Results Based Management, Theory of Change, Not for Profit Organizations (NPOs), Logical Framework, Performance, Monitoring and Evaluation

\section{Introduction}

The concept and practice of Results Based Management (RBM) have been developed and refined over a period of time to give impetus to the development programmes undertaken by the civil society organizations, also known as the 'non-profit' or 'Not for Profit' organizations (NPOs). Primarily it was to ensure delivery of results in terms of social benefits to people and to maintain eligibility for securing continued technical and financial support from international development agencies. The term RBM soon became a synonym for high performance, efficiency and quality, and consequently earned laurels among communities as well as claimed global recognition including within the UN system. The RBM is essentially based on the 'Theory of Change' $[1,2]$ pursued by the global community both in the corporate sector and by development professionals to make the world a better place through broader engagement of people, in particular those left behind.

In the forthcoming discussion the above gradual drive to introduce RBM is used as a basis to build arguments to compare and equate RBM with other quality management systems, widely practiced by the (for profit) corporate sector and multinational organizations, such as the ISO 9000 series and Total Quality Management (TQM) guidelines. This particular perspective has neither been debated in the Quality Management context nor in RBM literature. However, due to successful and sustained adherence to RBM practice by a large number of government departments and civil society organizations in planning, monitoring and evaluation of development programmes including the Millennium Development Goals (MDGs; appendix-1) and its successor agenda of Sustainable Development Goals (SDGs; appendix-2), it 
has become imperative to discuss and assert the role of RBM in Quality Management.

A brief description of quality management concept and existing systems with examples is given below to set the stage.

The 'Quality' is defined in a variety of ways in the context of work undertaken by organisations, e.g. the manufacturing sector (especially automobile) describes quality as 'fit for use' [3] which is broadly accepted and applied across a range of industries. The narrative denotes performance and customer satisfaction. It is achieved through adopting 'Quality Management' system which is a set of standards. 'Organizations use the standard to demonstrate the ability to consistently provide products and services that meet customer and regulatory requirements' [4]. These standards are measured against planned targets, values and criteria to ensure achievement of the desired level of excellence in whatever we do, produce or deliver.

Three key terms are used in the context of quality management.

- Quality assurance to oversee compliance to work processes.

- Quality control to oversee compliance to standards set for products and deliverable services.

- Continual Improvement to draw and incorporate lessons in work as not to commit same errors over and over again, and to sustain and further enhance the level of excellence already attained.

This last element is connected with the process of continuous improvement and promotes the PDCA model [5] (appendix13) which is a familiar practice among corporate managers.

The QM Systems have been developed at various forums through iterative process. 'An iterative process is a process for calculating a desired result by means of a repeated cycle of operations and/or discussion. It should be convergent, i.e., it should come closer to the desired result as the number of iterations increases' [6]. Some of the forums and formats are global institutions such as the International Standards Organization (ISO), QMS and PDCA - an acronym for Plan, Do, Check, Act - introduced by Deming also known as Deming Cycle [7], the European Union, International Development Research Centre (IDRC), the OECD Development Assistance Committee (DAC) and the United Nations agencies.

We have conducted a brief study of major quality management systems' key criteria to understand if and how the RBM meets and applies the same criteria to be declared as a quality management system. The Comparative Chart of the five systems is provided in Table 1. It includes:

i. ISO 9000 series/9001 (Universal)

ii. Total Quality Management Concept (Universal) iii. European Framework for Quality Management (Europe)

iv. Malcolm Baldrige Award (USA)

v. Results Based Management System (Universal specific to UN/NPOs)

The purpose of all these conceptual models and practices is to enable managers to ensure attainment of high-end products and performance standards in the delivery of work. The organizations aspiring to improve and sustain high performance pursue international quality standards for potential benefits including consistently providing products and services that meet customer satisfaction and statutory and regulatory requirements [8].

The Switzerland based agency that has developed the ISO 9000 series is universally recognized. ISO 9000 series is a set of international standards on quality management developed to help companies effectively document the quality system elements to be implemented in order to maintain an efficient quality system. This standard lays out the fundamentals and vocabulary of quality management systems (QMS) [9]. ISO 9001 provides guidance regarding mapping and defines essential organizational processes and their interrelation according to quality standards for certification. [10] The ISO 9001 (version 2015) particularly focuses on leadership, transparency and risks and opportunities.

The TQM approach takes into consideration the long term planning and customer satisfaction [11] whereas the Malcolm Baldridge Award is typically an American concept to encourage the corporate sector manufacturing and service companies to excel in performance and claim the award to inspire the market actors for competition.

The EFQM is the brain child of EU leadership [12] having its roots in the concept of human rights' protection and social development as part of the economic and political agenda. 'The new EFQM Model places an unparalleled emphasis on the importance of purpose, vision and agile strategies to organizations if they are to create sustainable value' [13].

The RBM system developed by the NPO sector is considered at par with these systems.

From a cursory look at Table 1 below, it is noted that despite the fact that these systems have been developed at different forums and at different times, yet the key criteria are focused on some common values, e.g. leadership, ethics, strategy planning, policies and processes, risk assessment, transparency/integrity, monitoring and measurement systems/ accountability, focus on customers/people and achievement of results. The ISO 9001 has the most comprehensive list of criteria that need strong organizational structure and resourcefulness whereas other systems are less demanding and are applicable to a host of organizations including budding enterprises in the government, corporate and social sector. 
Table 1. Major Quality Management Systems' Criteria

\begin{tabular}{|c|c|c|c|c|}
\hline \multicolumn{5}{|c|}{ Major Quality Management Systems' Criteria } \\
\hline QM - ISO 9001-2015 & $\begin{array}{l}\text { TQM - Total Quality } \\
\text { Management }\end{array}$ & $\begin{array}{c}\text { EFQM - European } \\
\text { Framework for } \\
\text { Quality Management }\end{array}$ & $\begin{array}{c}\text { Malcolm Baldrige } \\
\text { National Quality } \\
\text { Award }\end{array}$ & $\begin{array}{l}\text { RBM - Results Based } \\
\text { Management }\end{array}$ \\
\hline Risks and opportunities & Ethics & Leadership & Leadership & $\begin{array}{l}\text { Leadership and } \\
\text { Stewardship }\end{array}$ \\
\hline $\begin{array}{l}\text { Organization's purpose, } \\
\text { strategic direction, goals } \\
\text { and aspirations, }\end{array}$ & Integrity & Policy and Strategy & Strategic Planning & Strategic partnership \\
\hline Policies \& Processes & Trust & People & $\begin{array}{c}\text { Customer and Market } \\
\text { Focus }\end{array}$ & Results-based Planning \\
\hline Leadership & Leadership & $\begin{array}{l}\text { Partnership and } \\
\text { Resources }\end{array}$ & $\begin{array}{l}\text { Measurement, Analysis } \\
\text { and Knowledge } \\
\text { Management } \\
\end{array}$ & $\begin{array}{l}\text { Monitoring and } \\
\text { Evaluation }\end{array}$ \\
\hline Resource Planning & Training & Processes & $\begin{array}{c}\text { Human Resource } \\
\text { Management }\end{array}$ & SMART* Indicators \\
\hline Communication & Teamwork & Customer Results & Process Management & $\begin{array}{c}\text { Participation and } \\
\text { Collaboration }\end{array}$ \\
\hline $\begin{array}{c}\text { Documented } \\
\text { information }\end{array}$ & Recognition & People Results & Business Results & Community Ownership \\
\hline Interested parties & Communication & Society Results & & Transparency \\
\hline $\begin{array}{l}\text { Control of externally } \\
\text { provided processes, } \\
\text { products and services }\end{array}$ & & $\begin{array}{l}\text { Key Performance } \\
\text { Results }\end{array}$ & & Accountability \\
\hline $\begin{array}{c}\text { Production and service } \\
\text { provision }\end{array}$ & & & & Sustainability \\
\hline $\begin{array}{c}\text { Quality objectives and } \\
\text { plans }\end{array}$ & & & & $\begin{array}{l}\text { Efficiency and } \\
\text { Effectiveness }\end{array}$ \\
\hline Design and development & & & & Risk mitigation \\
\hline Sustainability & & & & Learning \\
\hline Transparency & & & & $\begin{array}{c}\text { Information sharing and } \\
\text { communication }\end{array}$ \\
\hline Customer satisfaction & & & & Social change \\
\hline
\end{tabular}

\section{Methodology}

A three-pronged approach is adopted in conducting the study as follows:

i Carried out a comparative study of selected international and regional/universal and specific Quality Management Systems by identifying and analyzing major criteria described to distinguish each system that resulted in developing Table 1 above.

ii Conducted the literature review of core material standardized by lead UN and civil society professional organizations on Results Based Management, followed by a series of intensive dialogue among the authors to reach conceptual clarity as to create the basis for launching the new theme.

iii Reviewed and selected relevant examples from a diverse range of social development and humanitarian projects across the globe including the once in which the authors were also engaged. Added these examples to the study for emphasizing the practical aspects of the concept.

\section{Discussion on Results Based Management for Quality}

\subsection{Conceptual Underpinning of RBM}

By UNESCO's definition, 'RBM is a broad management strategy aimed at changing the way institutions operate by improving performance, programmatic focus and delivery. It reflects the way an organization applies processes and resources to achieve interventions targeted at commonly agreed results' [14].

The use of the phrase 'Results Based Management' [15] was initially popularized among the civil society organizations implementing programmes and projects through UN funding for socio-economic development of masses in the least developed and developing countries 
across the globe. The United Nations system adopted the Results Based Management (RBM) approach in 1997 to improve the quality of its products and services among its many agencies and associated bodies and introduced it among its implementing partners in member states. Since then, the RBM is known as the 'Gold Standard' to achieve high quality and high performance in the delivery of development agenda.

It is in place to differentiate between the RBM and other universal concepts of QMSs. The RBM has its niche in addressing performance and quality matters in the planning, execution, monitoring and evaluation of development and humanitarian programmes especially the ones supported by the UN system.

The RBM is aimed at delivering efficient, effective and sustainable projects for communities, particularly benefiting those segments of population left behind due to grave social inequalities, economic disparities and perpetuating poverty.

Many organizations adopted the RBM as a management strategy focusing on performance and achievement of a hierarchical chain of results namely outputs, outcomes and impacts [16] with each component contributing to the next level [17]. 'The links between various levels of results are as important as the results themselves, reflecting the theory of change and the roles of providers and other stakeholders' [18].

The RBM approach is formed around the following themes:

- Common vision (among Stakeholders)

- Leadership and Stewardship

- Ownership and Partnership

- Capacity Building

- Reform of budget processes and financial management

- Realistic outcomes and simplicity

- Devolution of authority

- Learning

- $\quad$ Evidence based decision-making

The above approach helps development managers, training and/or service providers ensure active engagement of stakeholders in the implementation of processes and delivery of outputs and services necessary to achieve clearly stated objectives. Accordingly, learnings from evaluation of results help in evidence based decision making by integrating lessons learned into management decisions and monitoring of, and reporting on performance [19].

Through participatory approach in planning, monitoring and evaluation, managers are able to remove hierarchical authoritative barriers and communication gaps among stakeholders. All actors (individuals and organisations) who contribute directly or indirectly to the result, map out their business processes, products and services, as an evidence of contribution to the outcome [20].

The message of the RBM is that irrespective of the nature, size and scope of the intervention, if it is directed to achieving results, there shall be a breakthrough at some point, and with persistence the situation shall change for the better, the poverty cycle shall be broken, illiteracy and epidemics shall be controlled and prosperity shall prevail.

There is a systematic monitoring process based on pre-defined indicators and comparative analysis to ensure that funds invested in a project are likely to produce 'value for money' in terms of social development and upward change in the quality of life of masses. Over a period of years since its adoption, the RBM system has evidently made a significant contribution to improving the quality of NPOs governance and programme/project management in numerous developing countries.

\subsection{Institutionalization of RBM}

The RBM's institutionalization is done at two levels: organizational and programme/project level.

At Organizational level, a strategic policy statement is essential to declare commitment of the organization to adopt and practice the RBM across all management levels. Its mainstreaming into the various units of the organization through a uniform system facilitates its application.

The strategy is being adjusted from time to time to cater for changing situations internally or externally to ensure that the commitment is constantly met and policy directives are truly complied with.

In the process of strategy development, the institutions need to undergo a self-evaluation and soul-searching exercise beyond scratching the surface, then engage external partners and communities in the discourse on setting a mission, a vision and objectives, as well as the means to achieve and verify the same beyond any political or bureaucratic influences.

The organizations and their leadership have an obligation to take into account the aspirations of the people/stakeholders from all strata of society including minorities in articulating strategic development goals based on an alignment between the national and community priorities.

For attaining sustainability and impact, it is critical to ensure that the change in government as a result of political processes should not affect the on-going development programmes. Rather, the relevant government authorities and departments need to observe due diligence in measuring the results, social change and the impact of the interventions including the environmental impacts during their tenure and assist in improving the national strategies as part of political agenda.

Other two organizational aspects are the open lines of communication among stakeholders and their ownership of the programme. Without ownership, it is not realistic to expect managers and partners to apply RBM approach in true sense. The commitment of the organization affords them the confidence in the system, avoids conflicting opinions and filters out the unnecessary process elements 
in the implementation of strategy.

At programme/project level, the hierarchy of results and planning and monitoring tools are mainstreamed into the programme/project cycle including pre and post programme activities e.g. the baseline of the current situation before the intervention and impact evaluation after to gauge the extent of change as a result of the intervention.

To support the above narrative, an example of programme/project cycle is given below in Figure 1, listing main phases and sub-activities within the purview of each phase of the programme [21].
The terms 'programme' and 'project' are used here interchangeably, although by definition a programme is an umbrella framework for topical intervention under which many projects are executed. However, the programme cycle approach is applied in both cases.

The cycle has three main phases comprised of many interconnected processes:

i. Programme planning and approval process;

ii. Programme implementation, monitoring and reporting process;

iii. Programme review process and lessons learned.
- Evaluation

- Self-evaluatoin

- 3rd party evaluation

- Financial audit

- Impact assessment

- Lessons learned \& incorporated in future planning

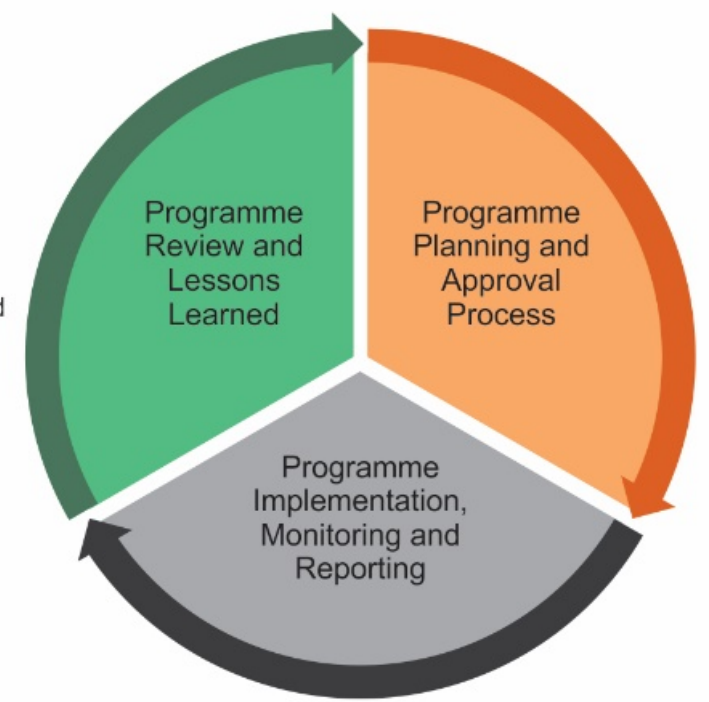

- Upstream work

- Baseline data collection

- Consultation

- Conceptualization

- Proposal development \& submission

- Appraisal for quality assurance

- Internal approval

- Approval by the board

- Operationalization

- Progress \& performance monitoring

- Reporting \& feedback

- Course correction

- Closure

Figure 1. Programme/Project Cycle - adopted from IAEA Technical Cooperation Model 
The planning process also called the upstream work includes stakeholders' analysis and consultative workshop to define problem(s) and explore solution(s) using the techniques of drawing a problem/solution tree, citing various levels of issues needed to be addressed through the project. A bottom-up approach contributes towards effective programming based on community needs and vulnerabilities and having 'SMART' [22] ideas in fixing the existing problems. Likewise, resource mobilization and allocation to priority areas and assigning roles and responsibilities of stakeholders is done through consultation.

At the programme/project designing stage Logical Framework Analysis (LFA) is conducted and subsequent to it the Logical Framework Matrix (LFM) is constructed that provides a concrete basis for planning, monitoring and evaluation. Each proposal goes through an approval process by the competent authority which in most of the cases is the Board of Directors (BOD).

Implementation of the project is carried out by the implementing agencies/partners in member states, and is monitored by their head offices responsible to ensure timely availability of resources (inputs) and delivery of services (outputs) at the desired level of quality with compliance to mutually established project processes, procedures and criteria.

Regular reporting is required on the progress and achievements of the project including citing challenges faced, addressed or not addressed. Some of the challenges are already considered at the time of the planning and noted in the LFM under 'Risks and Assumptions'.

A thorough review of the programme is conducted at the closure of the operation whereas the long term impact of the programme is captured after a considerable lapse of time e.g. 3-5 years down the line. The techniques for impact assessment are varying depending on the purpose of the exercise. Normally, key performance indicators (KPIs) and qualitative and quantitative targets are selected vis-a-vis the baseline information and according to the resources provided and partners' capacities for the kind of intervention.

It is hard to attribute change solely to the programme/project intervention due to the reason that external factors play a significant role in the development process. For example, promulgation of a law or adoption of a policy can change the scenario in favour or against the well-directed progress in any area of work. Similarly, public acceptance of the programme is critical for the ultimate success of the programme.

A citable example is that of the vaccination programme for children which has seen tremendous ups and downs during the last few decades due to changing public opinion and resistance to accept the programme in many developing countries resulting in the re-emergence of polio.

Administratively, the RBM system works through a multi-level chain of offices which are not necessarily sub-ordinate or hierarchical but with specific roles and responsibilities as described in the following Table 2, which is self-explanatory.

Table 2. RBM Administrative Structure - General Overview

\begin{tabular}{|c|c|c|c|}
\hline Institution & Contribution & Role & Description \\
\hline $\begin{array}{l}\text { Fundingg Partners } \\
\text { Funding partnership } \\
\text { within the RBM works } \\
\text { closely with the } \\
\text { leadership }\end{array}$ & $\begin{array}{l}\text { Financial Input } \\
\text { (At time coupled } \\
\text { with technical } \\
\text { advice) }\end{array}$ & $\begin{array}{l}\text { Provide funds for development } \\
\text { and/or emergency programmes } \\
\text { and interventions, conduct } \\
\text { overall monitoring of } \\
\text { disbursements, utilization of } \\
\text { funds and accountability of } \\
\text { executing agency. }\end{array}$ & $\begin{array}{l}\text { Financial input comes from many sources and in many } \\
\text { forms; however the main and the most desirable is the } \\
\text { cash contributions, grants and soft loans that come } \\
\text { from the government, the funding partners such as UN } \\
\text { organizations, International and National } \\
\text { Development agencies, International Financial } \\
\text { Institutions, contributions from CSR companies. }\end{array}$ \\
\hline $\begin{array}{l}\text { National, Regional and } \\
\text { International } \\
\text { Development } \\
\text { Organizations and } \\
\text { Departments } \\
\text { Leadership/ Senior } \\
\text { management level within } \\
\text { the RBM system }\end{array}$ & $\begin{array}{c}\text { Conceptual, } \\
\text { Organizational } \\
\text { and Technical } \\
\text { Input }\end{array}$ & $\begin{array}{l}\text { Identifying issues, setting } \\
\text { objectives and develop } \\
\text { programme proposals, define } \\
\text { targets and SMART KPIs, } \\
\text { mobilize/deploy resources, } \\
\text { engage implementation } \\
\text { partners, build capacities and } \\
\text { facilitate launching of } \\
\text { programmes according to their } \\
\text { mandate. }\end{array}$ & $\begin{array}{l}\text { It includes a wide range of development organizations } \\
\text { whose work is aimed at improving the quality of life of } \\
\text { people in general and addressing specific issues } \\
\text { related to poverty, social development, education, } \\
\text { health, environment, human rights, democracy and } \\
\text { justice systems, issue of exclusion/inclusion and } \\
\text { inequalities in the society. Their mandate is either } \\
\text { self-defined or extracted from another supra national } \\
\text { organization such as the United Nations. }\end{array}$ \\
\hline $\begin{array}{l}\text { Country Offices } \\
\text { Intermediary level of } \\
\text { programme / project } \\
\text { within RBM system }\end{array}$ & $\begin{array}{l}\text { Technical, } \\
\text { Physical and } \\
\text { Material Input }\end{array}$ & $\begin{array}{l}\text { Participate in the programme } \\
\text { development, prepare work } \\
\text { plans and organize resources, } \\
\text { execute projects, monitor } \\
\text { implementation progress and } \\
\text { report. }\end{array}$ & $\begin{array}{l}\text { The country office representing national, regional and } \\
\text { international organizations is the link between the } \\
\text { head office and the implementing agencies. It } \\
\text { participates in programme development, execution } \\
\text { and facilitation including resource management, } \\
\text { coordination, and communication, as well as } \\
\text { reporting. }\end{array}$ \\
\hline $\begin{array}{l}\text { Implementing agencies } \\
\text { (NPOs national } \\
\text { organizations; } \\
\text { community or } \\
\text { community based } \\
\text { organizations) } \\
\text { Grass root/ primary level }\end{array}$ & $\begin{array}{l}\text { Material and } \\
\text { Social Input }\end{array}$ & $\begin{array}{l}\text { Deliver goods and services to } \\
\text { communities }\end{array}$ & $\begin{array}{l}\text { NPOs are located close to or within the area of } \\
\text { intervention and are familiar with the local } \\
\text { socio-cultural environment. These organizations have } \\
\text { direct interaction with people whom they are } \\
\text { providing a range of goods and services within the } \\
\text { framework of the contract made with country offices } \\
\text { with specific budget, material and technical support. }\end{array}$ \\
\hline
\end{tabular}




\section{RBM Implementation}

Successful implementation of RBM is supported by the following essential elements.

\subsection{RBM Programme/Project Planning Process and Tools}

Planning with RBM requires specific tools and techniques. Some are applicable at organizational level and others at programme/project level. Together, these tools provide objective and concrete understanding of the work and its challenges.

\subsubsection{SWOT Analysis}

At organizational level the most critical analysis is called the SWOT analysis, an acronym for Strengths, Weaknesses, Opportunities and Threats. It is made of two by two matrix listing in each specific quadrant the relevant properties of the organization. It is primarily an internal exercise. Through SWOT analysis, the managers identify the strengths and weaknesses in the management and operation of the organization, its internal working conditions and external environment; also recognize opportunities and threats affecting the performance and success of the intervention. It helps to build upon the positive aspects and address the negative ones, simultaneously mitigating any possible internal threats and external risks. Protecting communities and the environment from any adverse effect of the project is utmost important. The main concern of the development agenda is 'do no harm' [23] which originated from the experience of work in the humanitarian crisis.

The following example in Table 3 identifies a set of selected positive/negative and internal/external elements that could impact the performance of an organization, sustainability of its programme, partnerships and at times, the very survival.

Table 3. An Example of SWOT Analysis - adopted from various sources [24]

\begin{tabular}{|c|c|c|}
\hline \multicolumn{2}{|r|}{ Positive (Helpful) } & Negative (Harmful) \\
\hline INTERNAL & \begin{tabular}{ll}
\multicolumn{2}{l}{ STRENGTHS } \\
- & Well-equipped Office and Labs \\
- & Competent Leadership \\
- & Diverse Team Skills \\
- & Motivated and Synergized Teams \\
- & Creditworthiness \\
- & Well-established Management Systems \\
- & IT Savvy
\end{tabular} & $\begin{array}{ll}\text { WEAKNESSES } \\
\text { - } & \text { Irregular Board Meetings } \\
\text { - } & \text { Lack of Strategic Planning } \\
\text { - } & \text { Lack of Succession Plans for the Future } \\
\text { - } & \text { Uncertain Funding Sources } \\
\text { - } & \text { Overload of Work } \\
\text { - } & \text { Luck of Security of Information } \\
\end{array}$ \\
\hline EXTERNAL & \begin{tabular}{ll}
\multicolumn{2}{l}{ OPPORTUNITIES } \\
- & Investment Opportunities \\
- & Low Interest Rates \\
- & Work Experience/Professional Growth \\
- & Networtry Exposure \\
- & Market Credibility \\
- & Innovation \\
- & Government Subsidies
\end{tabular} & \begin{tabular}{ll}
\multicolumn{2}{l}{ THREATS } \\
- & Lack of External Funding \\
- & Inflationary Trends \\
- & Chstable Business Environments \\
- & No-availability of Competent Personnel in the \\
& Market \\
- & Team Members Personal/Health Issues \\
High Rate of Employees' Insurance
\end{tabular} \\
\hline
\end{tabular}




\subsubsection{Risk Analysis}

It is a systematic process to safeguard the organization against unexpected upheavals, incidences and/or factors that may jeopardise its stability, continuity and performance.

Risk analysis helps to comprehend the nature of risk and to express the risk, with the available organizational and programme knowledge so that timely mitigation measures are planned and implemented.

Risk analysis should be understood and interpreted in a broader way. The Society for Risk Analysis (SRA) community defines risk analysis to include risk assessment, risk characterization, risk communication, risk management, and policy relating to risk, in the context of risks of concern to individuals, to public and private sector organizations, and to society at a local, regional, national, or global level [25].

There are various methods to conduct risk analysis. It is advisable that such an exercise is carried out through participation of stakeholders so that risk mitigation plans are also drawn together and an ownership is established in the outset.

The types of risks include human, social, political, governance, economic, sectoral, fiduciary, institutional, reputational as well as technical and environmental. Some risks are converted into assumptions and incorporated in the Logical Framework Matrix (LFM) in the outset.

The risk analysis findings are recorded in a risk register which is maintained by one of the senior management staff member or risk committee if the organization could afford to establish one.

Identified risks are being monitored constantly to ensure that the organization's sustainability and success of the programme/project are not compromised.

A generic specimen of risk register format is provided in Table 4 consisting of critical information and actions, in case a particular risk occurrence is probable or has taken place. The register record shows what (risk), occurred when and where. What was its intensity, frequency and impact? How and by whom was it mitigated and what the current status is as of the date of writing? Such record keeping of risks helps in the future planning for risk reduction and preparedness in anticipation.

Table 5 further describes various real-life examples of risks and mitigation strategies adopted by project teams of which the authors were also a part.

Table 4. A Generic Format of Organization and Programme Risk Register

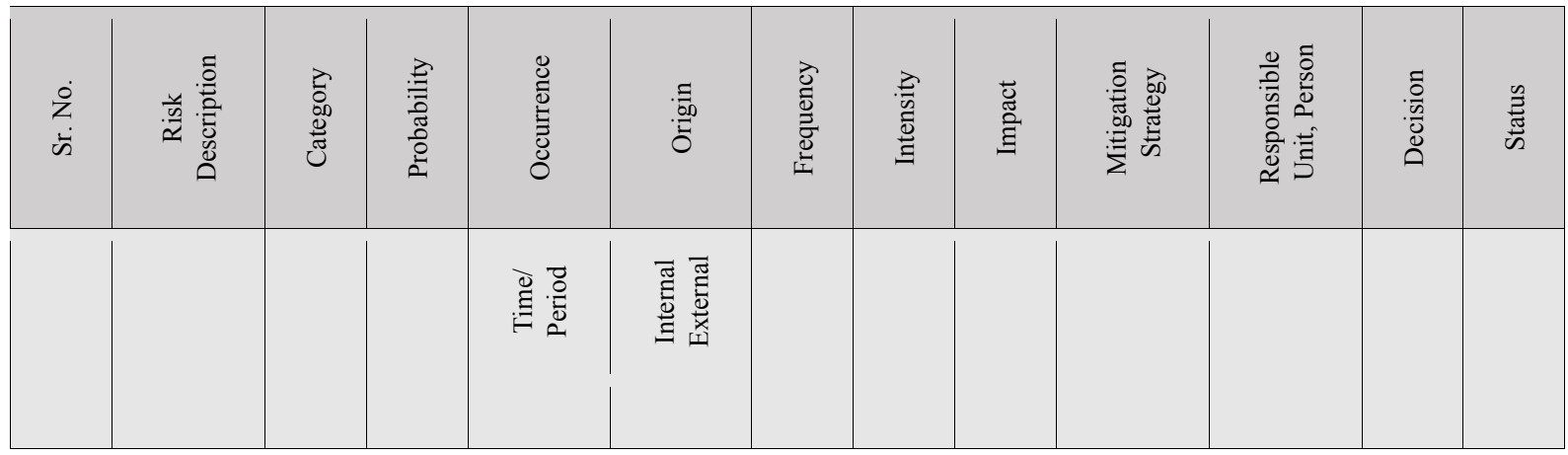

Table 5. Examples of Major Organizational and Programme Risk Indicators and Mitigation Strategy Adopted from NDRMF Risk Assessment and Mitigation Strategy)

\begin{tabular}{|c|c|c|c|c|c|}
\hline S. No. & Indicators Describing Major Risks & Risk Assessed & Risk Domain & Int., Ext. & Mitigation Strategy \\
\hline 1 & $\begin{array}{l}\text { Governance } \\
\text { - Lack of compliance to Security and } \\
\text { Exchange Commission or competent } \\
\text { registration authority rules and } \\
\text { regulations in the formation and } \\
\text { functionality of the Board of Directors } \\
\text { (BOD) and General Body (GB) } \\
\text { Slack in the frequency of Board of } \\
\text { Directors (BOD) / General Body (GB) } \\
\text { communication and meetings } \\
\text { - Lack of quorum in meetings } \\
\text { - Delays in decision making } \\
\text { Delays in implementation of decisions } \\
\text { and follow up } \\
\text { Quality of overall performance }\end{array}$ & M & Organizational & $\begin{array}{c}\text { Internal \& } \\
\text { External }\end{array}$ & $\begin{array}{l}\text { Ensure adherence to SEC } \\
\text { rules; keep track record of } \\
\text { BOD/GB meetings, } \\
\text { decisions and follow up; } \\
\text { facilitate communication } \\
\text { among BOD members; } \\
\text { maintain complete } \\
\text { documentation and record, } \\
\text { report any irregularities to } \\
\text { the competent authority. }\end{array}$ \\
\hline
\end{tabular}




\begin{tabular}{|c|c|c|c|c|c|}
\hline S. No. & Indicators Describing Major Risks & Risk Assessed & Risk Domain & Int., Ext. & Mitigation Strategy \\
\hline 2 & $\begin{array}{l}\text { Occupational Health and Safety (OHS) } \\
\text { Risks: } \\
\text { - } \quad \text { Incorrect or zero assessment of health } \\
\text { and safety at the workplace } \\
\text { - Workplace environment uncongenial } \\
\text { - } \quad \text { Overcrowding, poor lights } \\
\text { Ventilation and heating and cooling } \\
\text { - } \quad \text { Dystems failure } \\
\text { Dangerous/fragile } \\
\text { including glass, contact with } \\
\text { dangerous chemicals, asbestos } \\
\text { Location and access to location, } \\
\text { emergency exits during an emergency }\end{array}$ & $\mathrm{L}$ & Structures & Internal & $\begin{array}{l}\text { Make OHS assessment; } \\
\text { prepare OHS standards and } \\
\text { regime; build necessary } \\
\text { infrastructure/exits; ensure } \\
\text { readiness; conduct drills; } \\
\text { create awareness, build } \\
\text { partnership with OHS } \\
\text { expert organizations like } \\
\text { ILO and WHO. }\end{array}$ \\
\hline 3 & $\begin{array}{l}\text { Continuity: } \\
\text { - } \quad \text { Change in Leadership } \\
\text { Change in the mandate of the } \\
\text { Organization } \\
\text { Disruption in communication/ } \\
\text { incomplete communications to } \\
\text { various audiences } \\
\text { - } \quad \text { Disruption of supplies and operations, } \\
\text { Staff turnover/Loss of staff } \\
\text { confidence } \\
\text { Loss of access to essential assets and } \\
\text { failure in the delivery of services to } \\
\text { public / customers }\end{array}$ & M & Operational & External & $\begin{array}{l}\text { Plan in advance for Board } \\
\text { \& CEO term rotation; } \\
\text { watch against strikes and } \\
\text { public protest; prepare for } \\
\text { emergencies; streamline } \\
\text { recruitment and HR } \\
\text { management processes; } \\
\text { provide incentives; keep } \\
\text { sufficient supplies and } \\
\text { stores; create back up } \\
\text { system. }\end{array}$ \\
\hline 4 & $\begin{array}{l}\text { Audit and Accountability: } \\
\text { - A lack or failure of accountability due } \\
\text { to weak internal controls/or } \\
\text { insufficient fraud detection and } \\
\text { mitigation measures } \\
\text { - Unsuspected leakage of funds by } \\
\text { mismanagement or fraud } \\
\text { - Adverse audit reports } \\
\text { - Failure to comply with audit } \\
\text { observations }\end{array}$ & M & Procedural & $\begin{array}{c}\text { Internal \& } \\
\text { External }\end{array}$ & $\begin{array}{l}\text { Establish strong internal } \\
\text { audit and oversight } \\
\text { system/teams; prepare and } \\
\text { review; Annual Audit } \\
\text { Reports; take follow up } \\
\text { action, share information } \\
\text { with stakeholders and staff. }\end{array}$ \\
\hline 5 & $\begin{array}{l}\text { Project Performance Risks: } \\
\text { - } \quad \text { Lack of efficacy and efficiency } \\
\text { - } \quad \text { Failure to deliver results } \\
\text { Lack of mitigation measures to } \\
\text { address capacity gaps } \\
\text { - Field monitoring restrictions due to } \\
\text { matters related to health, safety and } \\
\text { security of staff } \\
\text { Weak reporting and data management } \\
\text { system to report programme/project } \\
\text { progress, success and / or failure } \\
\text { Insufficient financial reporting } \\
\text { affecting decisions } \\
\text { Force Majeure due to unforeseen } \\
\text { events }\end{array}$ & M & $\begin{array}{c}\text { Project, } \\
\text { Operational }\end{array}$ & $\begin{array}{c}\text { Internal \& } \\
\text { External }\end{array}$ & $\begin{array}{l}\text { Sustained capacity building } \\
\text { of implementing partners; } \\
\text { systems alignment } \\
\text { including timeline with } \\
\text { programme objectives and } \\
\text { results framework; } \\
\text { continuous oversight; } \\
\text { establishing robust data } \\
\text { management systems; } \\
\text { preparedness and planning } \\
\text { for unforeseen events. }\end{array}$ \\
\hline 6 & $\begin{array}{l}\text { Financial Risk: } \\
\text { - } \quad \text { Funding is exhausted with no } \\
\text { prospects of future investment } \\
\text { - } \quad \text { Lon-availability of sufficient funds } \\
\text { Lack of donors interest / failure to } \\
\text { promote, show case and promote } \\
\text { multi-year commitments with existing } \\
\text { and new donors } \\
\text { Downward change in bank interest } \\
\text { - } \quad \text { Fluctuation in corporate tax rate } \\
\text { - } \quad \text { Restructuring of fund portfolio } \\
\text { Failure to ensure value for money } \\
\text { Trust deficit between donor and } \\
\text { recipient institution }\end{array}$ & $\mathrm{H}$ & Financial & $\begin{array}{c}\text { Internal \& } \\
\text { External }\end{array}$ & $\begin{array}{l}\text { Financial planning } \\
\text { according to available } \\
\text { resources; forecasting and } \\
\text { fund mobilization strategy } \\
\text { in place; tax exemption; } \\
\text { investment options from } \\
\text { banking institutions; } \\
\text { safeguard against inflation } \\
\text { and exchange rate } \\
\text { fluctuations; flexibility for } \\
\text { addressing unforeseen } \\
\text { events. }\end{array}$ \\
\hline
\end{tabular}




\begin{tabular}{|c|c|c|c|c|c|}
\hline S. No. & Indicators Describing Major Risks & Risk Assessed & Risk Domain & Int., Ext. & Mitigation Strategy \\
\hline 7 & $\begin{array}{l}\text { Modernization and Innovation: } \\
\text { - Advances in technology beyond } \\
\text { resources, and/or lack of } \\
\text { competencies of technical teams } \\
\text { - Technical system failure } \\
\text { - System design failure/lack of back-up } \\
\text { Unsuitable working environment for } \\
\text { equipment and automation }\end{array}$ & $\mathrm{L}$ & $\begin{array}{l}\text { Technical, } \\
\text { Operational }\end{array}$ & Internal & $\begin{array}{l}\text { Identify technological } \\
\text { requirements and review } \\
\text { from time to time; keep } \\
\text { abreast of innovations; plan } \\
\text { for technical upgradation } \\
\text { and capacity building of } \\
\text { relevant staff. }\end{array}$ \\
\hline 8 & $\begin{array}{l}\text { Government Support Risk: } \\
\text { - Competing government priorities } \\
\text { - Change in government/country level } \\
\text { political scenario, nepotism, } \\
\text { corruption and inefficiency (which } \\
\text { may have an impact on top } \\
\text { leadership) } \\
\text { - Change in policies } \\
\text { - Lack of Government commitment } \\
\text { - } \quad \text { Foreign influence/donor influence } \\
\text { Languid Bureaucratic systems }\end{array}$ & $\mathrm{H}$ & Political & External & $\begin{array}{l}\text { Readiness for adjustment to } \\
\text { changing policies; keep up } \\
\text { with current and futuristic } \\
\text { trends; engage government } \\
\text { bodies on relevant subjects; } \\
\text { share information; identify } \\
\text { supporting forums, assert } \\
\text { and advance institutional } \\
\text { goals. }\end{array}$ \\
\hline
\end{tabular}

Risks are categorized as high, moderate and low. High-risk projects are 'no go' from the start. Risks rated as 'moderate' are addressed early in the planning so that the time and resources secured for investment in the programme do not go waste. Risks rated as 'low' are manageable during the programme implementation. Some 'low' risks are also accepted in the greater interest for delivering significant services and benefits to the majority of population.

Most of the development programmes are grossly affected by the change in government or change in government policies, shifting priorities and financial constraints. The RBM strategy should be able to cater for such changes and provide direction to managers for making realistic decisions.

\subsubsection{Stakeholders' Analysis}

At programme level, the first step in planning is to conduct a stakeholders' analysis to bring the development partners including government authorities, collaborators, funding partners, beneficiaries and development interest groups that have a stake in the programme and will be affected either positively or negatively with its implementation. This exercise explores the various stakeholders' capacities and competencies to contribute to the programme in any material or non-material way including the moral support from all segments which is an asset to the organization. It may include community elders, local government officials, male, female and youth, minorities, indigenous people, persons with disability (PWDs), professional groups such as teachers, religious guides, doctors, lawyers, technical/semi-technical individuals, athletes and artisans and any other group present in that area. It brings all the concerned parties at one platform and creates a sense of community ownership.
Any internal or external conflict is resolved during the process. Local resources and participation opportunities are identified and deployed during programme/project implementation phase.

A good analysis is able to answer the following questions:

- Who are the most important stakeholders?

- What is the stakeholders' knowledge of the policy?

- What are the stakeholders' positions on the specific policy?

- What do the stakeholders see as possible advantages or disadvantages of the policy?

- Which stakeholders might form alliances? [26]

The below Figure 2 is a reproduction of an example by PMI [27] that depicts the universe of Stakeholders placed around a project. The universe is large as almost every segment of the society at one point or the other could be considered a stakeholder if it is affected directly or indirectly by the project. Therefore, it is useful for practitioners to identify relevant stakeholders according to the need of the programme/project. For example, in a typical health project, the public health department, medical personnel/health service providers, donors and communities have a direct stake whereas vendors, supplies, academia or media have a marginal interest in the project, but indirectly benefit from its operations.

Once the stakeholders are selected as shown in green colour circles in Figure 2, an analysis is carried out at the pattern of the template provided in Table 6. It looks at the specific role of each stakeholder, his/her importance to and influence on the project as well as the expectations both from the project and from the stakeholder. According to PMI guidance, the analysis helps to understand the needs and expectations of the stakeholders and plan how to use their influence to ensure support in achieving project results [28]. 


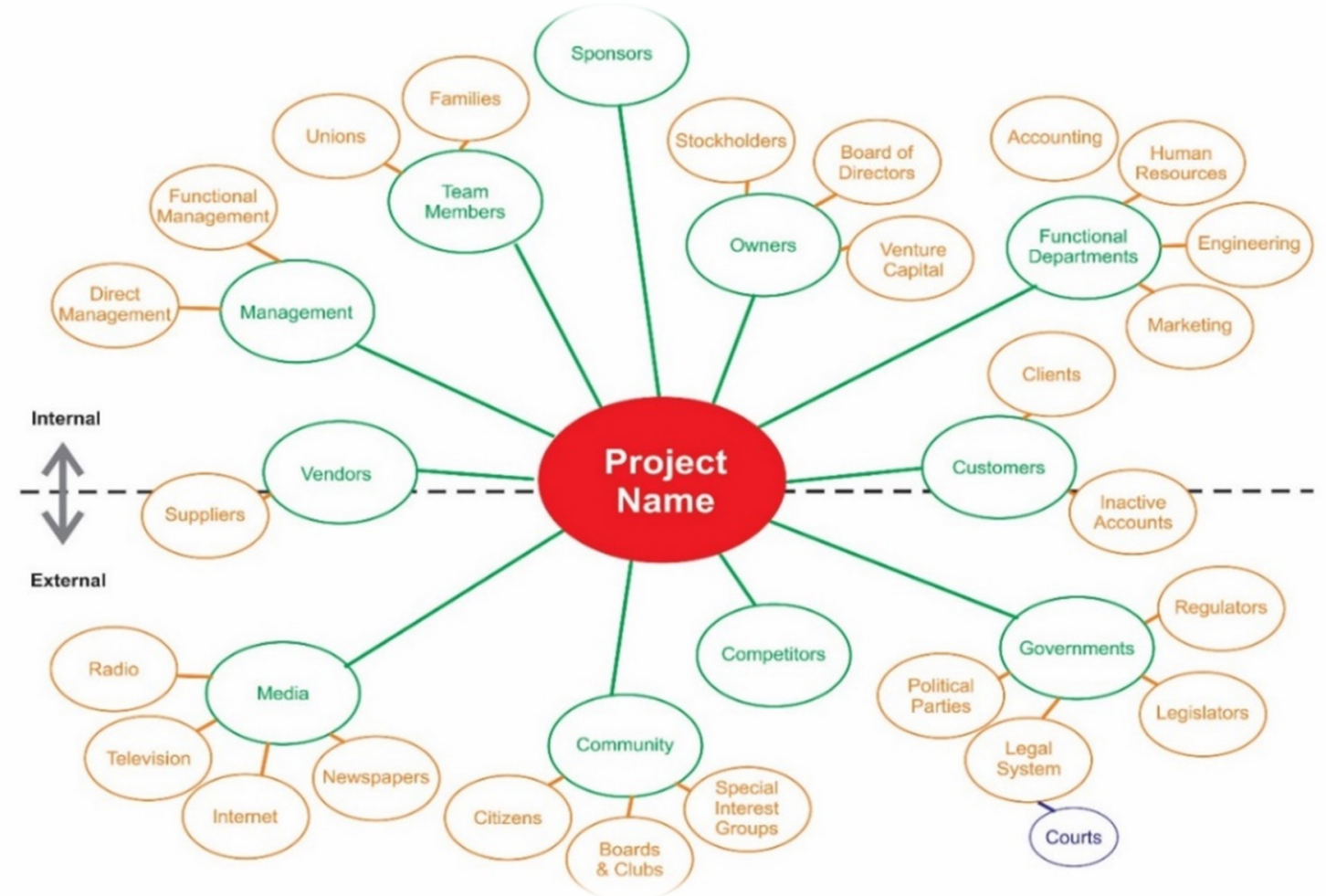

Figure 2. PMI's Example of Stakeholders' Universe around the Project

Table 6. Stakeholders' Analysis Template [29]

\begin{tabular}{|c|c|c|c|c|c|c|}
\hline \multicolumn{9}{|c|}{ Stakeholder's Analysis } \\
\hline $\begin{array}{c}\text { Stakeholder's } \\
\text { Name/Role }\end{array}$ & $\begin{array}{c}\text { How } \\
\text { Important? }\end{array}$ & $\begin{array}{c}\text { Current Level of } \\
\text { Support }\end{array}$ & $\begin{array}{c}\text { Project's } \\
\text { Expectations }\end{array}$ & $\begin{array}{c}\text { Stakeholder's } \\
\text { Expectations }\end{array}$ & $\begin{array}{c}\text { Stakeholder's } \\
\text { Influence }\end{array}$ & $\begin{array}{c}\text { Strategy to } \\
\text { Ensure } \\
\text { Support }\end{array}$ \\
\hline & $\begin{array}{c}\text { (Low, Medium, } \\
\text { High) }\end{array}$ & $\begin{array}{c}\text { (Low, Medium, } \\
\text { High) }\end{array}$ & & & (Positive/Negative) & \\
\hline & & & & & & \\
\hline
\end{tabular}

\subsubsection{Establishing Programme/Project Baseline}

Prior to proposal development, the management team and staff together with the implementing partner organizations and communities (if possible) are required to make sure that the baseline data on the subject / area of intervention is available and validated. 'The baseline is the first measurement of an indicator. It sets the current condition against which future change can be tracked' [30]. It may include demographic data, socio-economic indicators, existing civic infrastructure and amenities and so on depending upon the programming needs. The selection of indicators for the programme chain of results or formulation thereof (in case pre-established indicators are not available) is to be done through consultative process.

Normally, baseline data is collected both through primary and secondary sources i.e. by asking the concerned respondents using questionnaires or checklists and/or by scanning the available reports, documents, material pertaining to the subject. Cross checking information via triangulation [31] helps in getting better quality and more realistic information whether quantitative or qualitative. It is cautioned that the guess work in establishing baseline is worthless and damaging as it causes loopholes in the planning and later in progress monitoring and evaluation of the impact of the project. The collection, organization and use of baseline information need to be expedited as the situation on ground is constantly changing that will result in making the information redundant. Providing information to users on time is equally important.

The data triangulation matrix given in Table 7, explains how each activity can be considered in the light of alternatives and how to apply triangulation in a certain case. For example in case a particular market research approach is adopted out of three options, it is ensured that the triangulation theory is applied and that the standard research criteria are met. Similarly, the data collection method is assessed and selected considering comparative costs, time and availability of human resources. Managers making such decisions are required to justify it to their seniors, the CEO or the Board of Directors in order to obtain approval for resource allocation to undertake the activity. 
Table 7. An Example of Data Triangulation Matrix [32]

\begin{tabular}{|c|c|c|c|c|}
\hline & Alternatives & $\begin{array}{c}\text { Triangulation } \\
\text { Strategy }\end{array}$ & Criteria & Decision \\
\hline $\begin{array}{l}\text { Market Research } \\
\text { Approach }\end{array}$ & $\begin{array}{l}\text { Explorative research } \\
\text { Descriptive research } \\
\text { Causal research }\end{array}$ & $\begin{array}{c}\text { Theory } \\
\text { Triangulation }\end{array}$ & $\begin{array}{c}\text { State of Knowledge } \\
\text { concerning research } \\
\text { objectives and information } \\
\text { needs } \\
\end{array}$ & \\
\hline $\begin{array}{l}\text { Basic Population \& } \\
\text { Sample Selection }\end{array}$ & $\begin{array}{l}\text { Full population survey } \\
\text { Sample survey } \\
\text { (Selection methods) }\end{array}$ & - & $\begin{array}{l}\text { Basic population size } \\
\text { Cost and time budget } \\
\text { Significance of certain } \\
\text { sample elements }\end{array}$ & \\
\hline $\begin{array}{c}\text { Derivative Demand } \\
\text { Research }\end{array}$ & $\begin{array}{l}\text { Yes } \\
\text { No }\end{array}$ & - & Degree of derived demand & \\
\hline $\begin{array}{l}\text { Forms of Data } \\
\text { Collection }\end{array}$ & $\begin{array}{l}\text { Primary data (PD) } \\
\text { Secondary data (SD) }\end{array}$ & $\begin{array}{c}\text { Data } \\
\text { Triangulation }\end{array}$ & $\begin{array}{c}\text { PD cost and time budget; SD } \\
\text { data availability, adequacy, } \\
\text { timeliness }\end{array}$ & \\
\hline $\begin{array}{l}\text { Types of Data } \\
\text { Sources }\end{array}$ & $\begin{array}{l}\text { Internal data sources } \\
\text { External data sources }\end{array}$ & $\begin{array}{c}\text { Data } \\
\text { Triangulation } \\
\end{array}$ & $\begin{array}{c}\text { Data availability } \\
\text { Research objectives }\end{array}$ & \\
\hline $\begin{array}{c}\text { Employed } \\
\text { Investigators }\end{array}$ & $\begin{array}{l}\text { Operational research } \\
\text { Institutional research }\end{array}$ & $\begin{array}{c}\text { Investigator } \\
\text { Triangulation } \\
\end{array}$ & $\begin{array}{l}\text { Personnel availability } \\
\text { Cost and time budget }\end{array}$ & \\
\hline Interview Instruments & Mixed Method Matrix & $\begin{array}{c}\text { Methodological } \\
\text { Triangulation }\end{array}$ & Mixed Methods Matrix & \\
\hline $\begin{array}{c}\text { Forecast } \\
\text { Instruments }\end{array}$ & Mixed Method Matrix & $\begin{array}{c}\text { Methodological } \\
\text { Triangulation }\end{array}$ & Mixed Methods Matrix & \\
\hline
\end{tabular}

\subsubsection{Problem/Solution Tree}

The managers, through consultative process with stakeholders identify local problems, their causes and effects on the community and explore and discuss various options to address these problems. The indigenous solutions are considered feasible and sustainable and lead towards self-reliance in the long run. Priorities are jointly defined and resources are allocated according to the priorities through consensus building.

Drawing a flow chart and/or a problem tree means to establish the hierarchy of problems that takes the stakeholders from the root cause of the problem to the top i.e. the issues appearing at the surface as a result, and to address each at its level as necessary, ignoring some minor issues and highlighting major issues which are the most relevant to the community. Its name is driven from the shape of the diagram which is interpreted as 'the trunk represents the focal problem, the roots represent its causes and the branches its effects' [33].

The following sequence of steps is similar to root-cause analysis method applied in corporate projects for problem solving and corrective action [34].

i. Identify the existing problems

ii. Define the core problem

iii. Relate the causes to the core problem iv. Describe the effects of the core problem

v. Analyze and rationalize the diagram [35]

Figure 3 provides an example from a project in a rural farm setting where various stratified problems have been identified to finally conclude that low yields are the cause for low income of farmers. However at the bottom the first issue that erupted among the discussants was un-liberalized input supply resulting in inequality of seed distribution. Limited resources for seed production, poor extension services and weak implementation for insecticide spray appeared at the second level.

The third level brought out many other issues related to access to credit and farm inputs, lack of information, etc.; and the fourth level exposed many other weaknesses such as poor soil management, limited disease and pest control.

The fifth level exposed a number of broader issues having environmental impact e.g. illegal mining in the area, high incidence of pests, declining soil fertility as well as unapproved planting.

Finally, the top of the tree highlighted that as a consequence, the farm yields were low affecting the income of farmers. The core problem in this case remained the un-liberalized policies and weak implementation of standard practices and un-equitable extension services provided to farmers. 


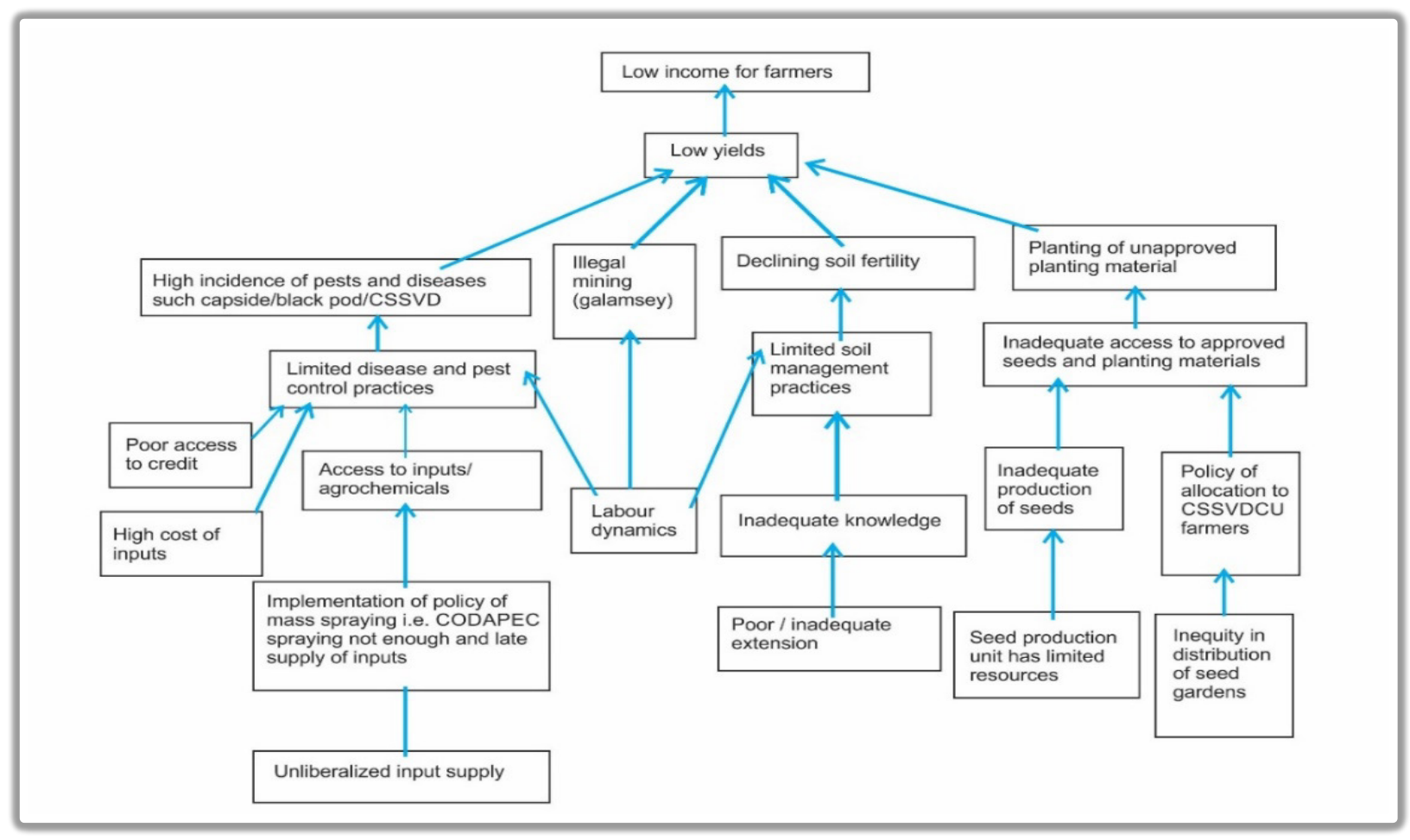

Figure 3. An Example of Problem Tree Diagram [36]

\subsubsection{Logical Framework Analysis (LFA) \& Logical Framework Matrix (LFM)}

The logical framework analysis is a tool to formulate programme/project objectives and hierarchy of results. It also includes activities to be carried out in order to achieve outputs and outcomes [37]. This information is organized in a $4 \times 4$ matrix called logical framework matrix (LFM).

The first column of LFM in Table 8 below consists of the 'Results Chain' also called the 'Hierarchy of Results' and the activities. The second column contains indicators against each element which are the basis for measuring progress during the implementation. The third column consists of means of verification and the fourth column contains assumptions to reflect upon the probability of achieving results. Assumptions are positive statements indicating that if certain conditions are met, there is a strong likelihood to materialize the planned results. The assumptions are drawn based on the risk analysis prior to defining means of verifications as indicated through arrows in Table 8 below.

Table 8. An Example of Logical Framework Matrix - adopted from UN System

\begin{tabular}{|c|c|c|c|}
\hline $\begin{array}{c}\text { I } \\
\text { Design } \\
\text { Element }\end{array}$ & $\begin{array}{c}\text { II } \\
\text { Indicators }\end{array}$ & $\begin{array}{l}\text { III } \\
\text { Means of } \\
\text { Verification }\end{array}$ & IV \\
\hline $\begin{array}{l}\text { Overall } \\
\text { Objective }\end{array}$ & $\begin{array}{l}\text { For Long Term } \\
\text { Impact }\end{array}$ & $\begin{array}{l}\text { Documented in } \\
\text { Organization's Policy } \\
\text { and Strategy }\end{array}$ & $\begin{array}{l}\text { Compliance with } \\
\text { Policy and Strategy; } \\
\text { Adherence to } \\
\text { Sustainability Criteria }\end{array}$ \\
\hline Outcome & $\begin{array}{l}\text { For Project } \\
\text { Success }\end{array}$ & $\begin{array}{l}\text { Documented Evidence } \\
\text { through mid-term or } \\
\text { terminal evaluations }\end{array}$ & Element of Change \\
\hline Output & $\begin{array}{l}\text { For Project } \\
\text { Deliverables }\end{array}$ & $\begin{array}{l}\text { Progress Reports and } \\
\text { Monitoring } \\
\text { observations }\end{array}$ & Units of Progress \\
\hline Activities & $\begin{array}{l}\text { Inputs and } \\
\text { Resources }\end{array}$ & $\begin{array}{l}\text { Financial and non- } \\
\text { financial resource } \\
\text { transfer }\end{array}$ & $\begin{array}{l}\text { Units of consumed } \\
\text { resources }\end{array}$ \\
\hline
\end{tabular}




\subsubsection{Quality Assurance Criteria for Development Programmes/Projects}

Proposal preparation is a lengthy and cumbersome process and needs to incorporate information obtained from the above exercises such as the baseline data, SWOT analysis, stakeholders' analysis, formulation of indicators against planned targets, and establishing the hierarchy of results. There are many different formats in use by the government departments, corporate sector and not-for-profit sector organizations; variations also occur due to the nature and the scope of the project. Baseline research and community development projects are the simplest form of it whereas development of large infrastructure or national health programme need considerable time and efforts including carrying out consultative process with high level partners, collaborators, sponsors as well as technical, scientific and legal teams.

The contents of project proposal may include:

\begin{tabular}{|rl|}
\hline \multicolumn{1}{|c|}{ Table of Contents } \\
i. & Description of the problem and intervention(s) \\
ii. & Justification \\
iii. & Stakeholders and Beneficiaries information \\
iv. & Results Framework Analysis (LFA) \\
v. & Deliverables and Timeline \\
vi. & Resource Plans including Budgets \\
vii. & Monitoring, Reporting and Evaluation Plans \\
viii. & and Timeline \\
& Project Leadership and Team Matrix of \\
\hline
\end{tabular}

In the preparation of a project proposal, the following criteria (as used in the IAEA Technical Cooperation Programme and many other UN agencies) help reviewers to objectively appraise the proposal for further process.

- Relevance: The programme should be relevant to the national priorities and fulfil one or more national development objectives.

- Ownership: It should be owned by the relevant government or its representative competent authority if it is designed at the national level; and owned by the community if it is designed at the local level/regional level to show commitment to implement the programme. The political will is critical to launch a development programme.

- Sustainability: It should be linked to an on-going national programme and or/its current and future resources including financial, human, technological and material resources which are being allocated without prejudice.
- Effectiveness: It is designed to ensure that the hierarchy of results is materialized as planned showing indicators of change on specific programme targets. Its benefits are accruing and/or will continue to accrue to the communities.

- Efficiency: Its budget and timeline are defined in accordance with the delivery of outputs, and an accountability mechanism is in place to fix responsibility for delays or budget overruns.

\subsection{RBM Programme/Project Implementation Process and Tools}

At the project inception, the most critical activity is the operationalization of the project using specific tools such as the Project Implementation Plan (PIP). The PIP reflects a set of activities to be executed over the project lifecycle and is drawn from the project plans agreed upon at the acceptance of the proposal as shown in the IAEA Programme Cycle Figure 1. It is also called the 'Milestone Plan' as described by the IUCN [38] below in Figure 4. The sequence of steps is:

i. Setting up the project for implementation, including the establishment of a project team and the creation of a milestone plan, either annual or biennial depending on the duration of the project.

ii. Implementation of activities, which includes managing the activities themselves, providing technical inputs to the project and if applicable, managing risks under an Environmental and Social Management Plan and cross cutting issues including Gender mainstreaming, protection of human/workers' rights and Grievance Redress system.

iii. Monitoring and reporting, inter alia the deployment of supervision missions as well as technical reporting covering the delivery of results and impacts. Monitoring activities consist of survey, assessments, remote sensing, and disseminating progress to relevant stakeholders for feedback; currently electronic Dashboards are used for the purpose.

iv. Updating the milestone (action) plan / PIP based on the results of monitoring and other management decision making.

v. Every project eventually ends or transits into a new phase. There are specific steps to be taken at the end of a project including financial and technical closure, reporting and terminal evaluation highlighting lessons learned.

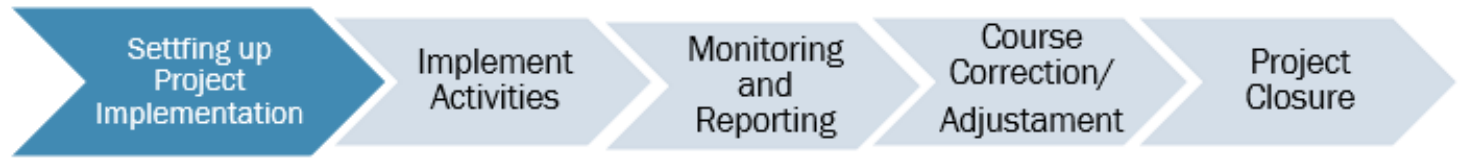

Figure 4. Project Cycle Implementation Milestone Plan 
For the purpose of this paper, three useful processes and tools are described i.e. the Project Implementation Process (PIP), M\&E system and the Closure Process.

\subsubsection{Project Implementation Plan (PIP)}

The PIP is drawn by the project team with stakeholders at the inception of the project as a road map to guide through the course of implementation. The PIP, according to Canadian International Development Agency (CIDA) guidelines, is the official plan that helps establish a vision for all stakeholders and through a combination of narratives, charts and matrices answers fundamental questions about the programme/project e.g. what we will do, who will do what, why, where, when and how as well as the deployment of resources [39].

There is a variety of formats used by practitioners based on information need. As long as the PIP is able to answer the above $6 \mathrm{Ws}$ and $1 \mathrm{H}$ formula, it is good to go.

The list of activities is drawn from the planning documents and is in particular linked to the LFM at various levels of results i.e. outputs, outcomes and impacts.

The PIP process promotes consensus building among all those partners and managers involved in the implementation. Some core activities include a Gantt chart to clearly define activities with timeline, budget and persons responsible to carry out these activities.

The PIP preparation, thus, involves field missions, consultative workshops, research, document review, planning meetings and team building.

In view of a diverse range of activities, reasonable time is allotted for the process [40]. The PIP example given in the following Table 9 is structured to provide a comprehensive project overview at a glance. The first column incorporates the outcomes and linking outputs taken from the LFM, which are monitored throughout the implementation process. The second and third columns describe relevant activities and inputs. The fourth column names the person(s) responsible.

The rest of the columns provide other necessary information regarding the start/end dates, budget and progress update of the project. It is a simple and practical user-friendly format.

Likewise, separate implementation plans are drawn for project components such as training, capacity building and community awareness.

Table 9. An Example of Project Implementation Plan

\begin{tabular}{|c|c|c|c|c|c|c|c|c|c|c|}
\hline \multicolumn{11}{|c|}{ Programme/Project Implementation Plan (PIP) } \\
\hline Outcome/Output & Activity & Input & Responsibility & Start Date & End Date & Budget & \multicolumn{4}{|c|}{ Status } \\
\hline & Description & Specified Action & Person(s) & & & & Completed & In Progress & \multicolumn{2}{|c|}{ Not Started } \\
\hline & & & & & & & & & Not Due & Delayed \\
\hline \multicolumn{11}{|l|}{ Outcome 1} \\
\hline \multicolumn{11}{|l|}{ Output 1.1} \\
\hline \multicolumn{11}{|l|}{\begin{tabular}{|l|} 
Output 1.2 \\
\end{tabular}} \\
\hline \multicolumn{11}{|l|}{\begin{tabular}{|l|} 
Outcome 2 \\
\end{tabular}} \\
\hline Output 2.1 & & & & & & & & & & \\
\hline Output 2.2 & & & & & & & & & & \\
\hline
\end{tabular}




\subsubsection{RBM Monitoring, Evaluation and Reporting}

Monitoring is one of RBM's essential functions. It is embedded in the programme cycle and provides impetus to the programme learnings, and feeds its findings into evaluation process. Since we are advocating participatory planning, obviously, the monitoring process also includes stakeholders' input which is reflected and utilized in the course correction and future planning.

The ten steps to a results-based monitoring and evaluation system [41] are designed in an orderly manner like a flow chart and are easy to practice. As shown in Figure 5, the monitoring and evaluation (M\&E) process starts from conducting a readiness assessment i.e. step 1 . In case an organization is not prepared or willing to conduct the M\&E exercise, it will be a waste of time and resources. Readiness means having accomplished a certain level of progress and achievement, availability of relevant record and documentation, access to information as well as cooperation from the staff. Most of all, the management decided to support the monitoring and evaluation process. It is also the management decision to agree on the outcome of the M\&E exercise including selection of key performance indicators and provide baseline data for monitoring purposes.

Steps 2-6 cover the activities related to the progress on indicators, and an evidence of achievements of planned results depicting change. Steps 7-10 include planning and undertaking evaluation, either internally or through a third party. Evaluation findings are used to plan future projects and, for learning purposes, to extract, use and share good practices that sustain the M\&E system

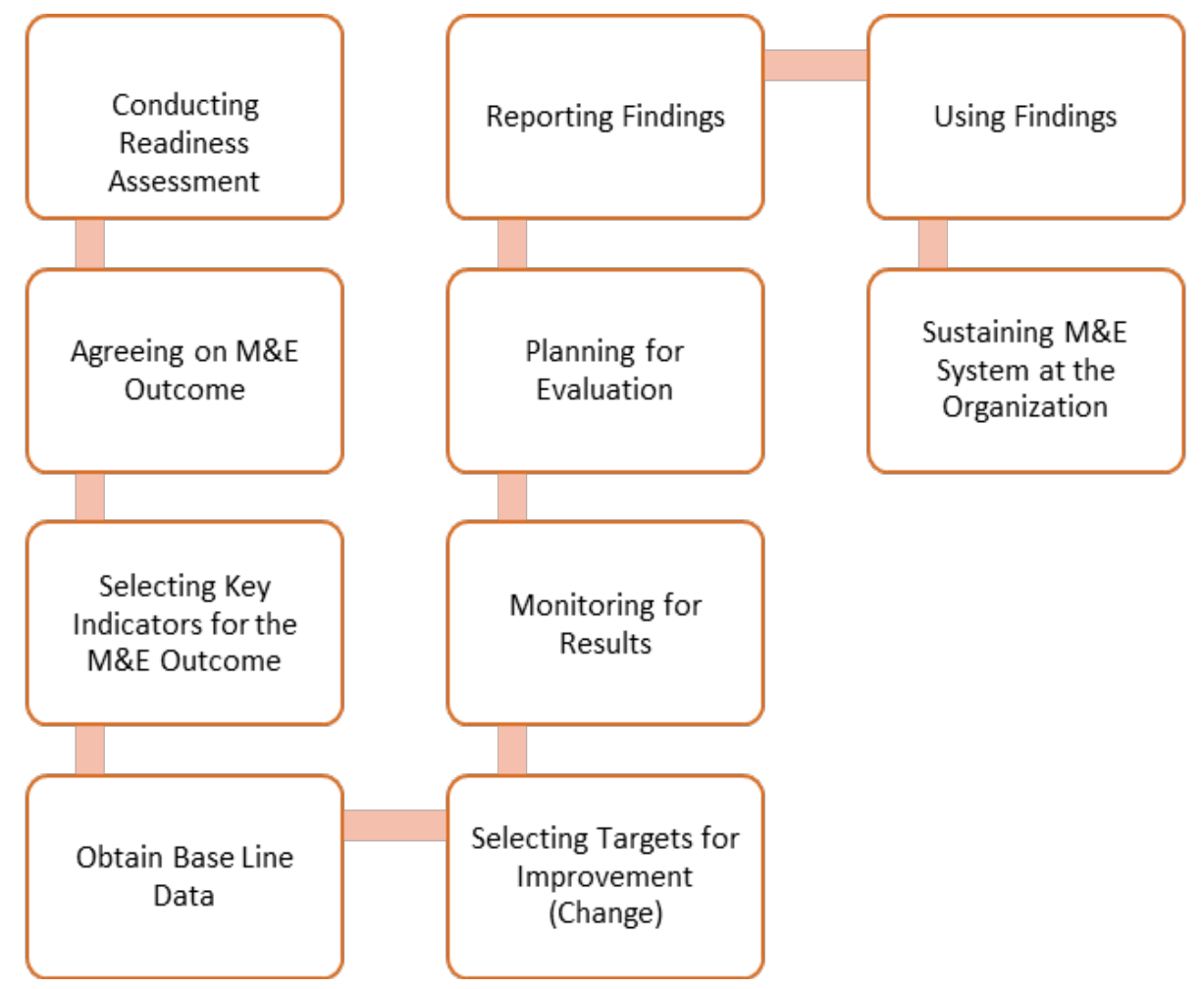

Figure 5. Ten Steps to a Results-Based Monitoring and Evaluation System 
The organizations' needs for information vary, so does the nature of monitoring. Some common monitoring and evaluation practices are cited here.

\section{- $\quad$ Progress Monitoring}

The purpose of this activity is based on management's information need for informed decision making. The progress monitoring on the already defined indicators falls into the regular monitoring system and its results are displayed on the dashboard for managers' quick reference. Progress monitoring locates gaps in reaching targets and allows timely course correction.

\section{- $\quad$ Performance Monitoring}

The performance monitoring goes beyond progress monitoring. It looks at the level of compliance with established standard procedures as well as good practices for excellence in achieving milestones, using innovative approaches to enhance and/or multiply the benefits of the project and going an extra mile to engage stakeholders and incorporate their ideas and address their concerns during the course of project execution.

\section{- $\quad$ Portfolio Monitoring}

Portfolio monitoring uses a series of indicators to assess financial health and implementation risk at the portfolio level, including the number and total value of projects secured and in the pipeline, diversity and size, donors, income and expenditure as well as cost and time over run [42].

\section{- Monitoring of Cross Cutting Issues}

NPOs, in particular those implementing global development agenda (e.g. SDGs) with UN support, are required to monitor the state of human rights and humanitarian situation including cross cutting themes such as the gender equity, child rights protection, environmental protection and status of minorities. These universal indicators should be included in the monitoring systems to ensure that there are no adverse effects of the project on the society. It is in line with various relevant international conventions and the Bill of Rights, ratified by a large number of UN member states.

\section{- Monitoring of Social Trends/Perception Surveys}

Monitoring of social trends within the scope of the programme is also important, particularly when the focus is on building people's attitudes towards adopting new ideas, policies, laws and regulations, technologies, systems and new products and markets.

\section{- Evaluation}

Unlike monitoring, evaluation is an intervallic activity that takes place at any given time before, during or at the end of the project. The pre-evaluation is called formative evaluation as it helps to design the future course of action, and the post-evaluation is called summative as it sums up the results of the projects and lessons learned. 'To evaluate something means determining its merit, worth, value or significance' [43]. The evaluation activity includes looking into the effectiveness of the programme from the perspective of its processes, implementation approach as well as results achieved. The three key questions asked are: What happened? So What? Now What? [44]

It is preferred to let the implementing agencies conduct a self-evaluation and validate a few aspects through third-party evaluation. It helps build the confidence of stakeholders and implementers and also creates an environment of mutual trust and ownership.

Despite the fact that evaluation is an important source of information and knowledge, there is a fear of evaluation amongst managers, due to the lack of trust in the ability of evaluators to appreciate achievements and give due consideration to challenges faced by the implementers. On the other hand, there is also time constraint that does not allow the evaluators to look into each and every aspect of work thoroughly. In such a case, the project team feels dissatisfied with the findings of the evaluators. The RBM addresses this dilemma by providing systematic monitoring input to evaluation and consolidating results through summative evaluation, citing good practices and highlighting challenges. It safeguards against the unexpected or shocking revelations at the close of the project.

The stakeholders' participation in evaluation provides mutual understanding on issues that need to be addressed in the future. A consensus is built between the evaluation team and project management and stakeholders on the findings of the evaluation. Finally everybody signs off to take ownership of the evaluation report.

\section{- Impact Assessment}

Finally, the stakeholders are keen to see if any change has taken place due to the intervention. It is difficult first of all to assess and measure the change and secondly to attribute it to a specific project. Hence, the subject is to be dealt with very carefully as not to create a false perception of success or failure. An objective evaluation cites programme's high and low points and also identifies if the change is for the better or for the worse. Realistically speaking, some changes could be attributed to the intervention under the given environment. Therefore, in case the risk and assumptions are correctly assessed and formulated at the planning stage, the impact assessment will be linked to it and meaningful interpretation of findings will be possible.

\section{- $\quad$ Reporting}

M\&E Reporting regime with specific reporting activities is built into the PIP as well as implemented through progress, performance and portfolio monitoring regimes. Normally, at the base level, the project team follows a frequent reporting approach on a daily, weekly or monthly 
basis, shared verbally, electronically or in hard copies. Among the hierarchy of offices within the organization, reporting needs are established from quarterly, semi-annually, annually to bi-annually. With the advancement in the electronic media, information is available in real time, however, documented and validated project related information is reported formally and used for future planning.

\subsubsection{Project Closure Process}

The final phase in the project cycle does not end with the closure. In fact the terminal evaluation and impact assessment are undertaken at the formal completion of technical and financial activities and submission of closure report.

There are two common ways of closing a project.

- Routine development projects within the portfolio of a large programme prepare individual closure reports citing achievements against planned targets based on LFM and submit a report together with financial record including expenditure incurred against each budget head and any allowable variations as per the agreement. Over spending is not a good performance indicator and is curbed during the implementation phase through progress monitoring and disbursement regime. RBM planning with costing and budgeting of item-wise equipment, operational expense and core activities leads to a successful closure of the project without time and cost overrun.

- On the other hand, complex projects go through a lengthy process in which the evaluation is trailed after the project financial and technical closure is declared and reported. This could also happen at the end of the project cycle or any time due to 'Force Majeure'. The reason for closure is provided in the outset to explain the natural end of the project cycle e.g. discontinuation due to early attainment of results, relevancy and justification fallacy, force majeure under various circumstances such as natural disasters, policy change, regime change, and economic and market instability including high inflation causing financial difficulties or any other unforeseen event.

The terminal evaluation is preferably carried out by a 'third party' to ensure neutrality and credibility of the findings. The relevant project team and partners are involved in the process and each opinion counts to reach conclusions.

A comprehensive closure report is drafted, discussed and finally accepted among partners for submission. Dissent opinion is cited in the report.

The evaluation report may include compliance to contract terms and conditions, the extent of attainment of results at various levels, internal and external challenges faced, assumptions materialized, risk mitigated, judicious utilization of financial resources acquired through investments, donations, loans and grants, record of recruitment of personnel and their roles and responsibilities, procurement of equipment and material, technical/design and engineering expertise and input utilized, and partnerships and collaboration.

The closure has several management aspects.

\section{- Technical Closure}

The technical closure denotes the end of activities related to the outputs leading to outcomes as subscribed and articulated in the LFM at the planning stage. In case of under-achievement, the reasons are to be explained and responsibility fixed through an assessment of the roles and responsibilities of the staff, partners, collaborators and/or any other stakeholder. The PIP is a good reference point for this purpose.

- Financial Closure [45]

Financial closure means that from this point onward, there shall be no activity in the project account such as deposit or withdrawal, transfer of funds, disbursements/payments except already issued cheques in process to be honoured by the bank, of which the information is provided in the financial statements. Although, the financial audit of the project is carried out on an annual basis, however, the closure stance requires a financial review to determine the status and cite any outstanding issues or variances taken place during the course of implementation. The audited financial statements i.e. Income and Expenditure Accounts and Balance Sheet are cleared by the Audit Firm and become part of closure report.

\section{- Administrative Closure}

This entails closing of administrative processes at the head office and field offices/project sites. It includes documentation of project life cycle and confirmation of completion of tasks related to administration, analysis of any major events, security, staff management, internal and external working environment and state of adherence to standard procedures as well as record of documentation and office supplies.

In addition, the project manager is responsible to conduct performance measurement and preserve project-related documents including plans, product specifications, technical documents, drawing and any other information (soft or hard) related to partners, collaborators and donors [46].

\section{- $\quad$ HR Management}

This entails departing packages for the staff no longer required in the post-project phase as well as those who will stay for a certain period of time to deliver specific assignments. The end of project also calls for fixing responsibility for non-achievement of outputs and/or non-compliance to project standard procedures during the course of implementation and closure.

- Risk Mitigation and Residual Risk Management 
Risk assessment conducted at the planning phase is reviewed and/or a fresh assessment undertaken at the end of the project to ensure that mitigation measures have effectively worked and only residual risk has to be managed as part of the post-project activities.

\section{- Asset Management}

Projects where procurement of equipment and machinery including office equipment and construction of infrastructure is involved, need to establish ownership, maintain an inventory of mobile and immobile assets, and procure insurance as well as operations and maintenance services. This covers the lifetime of the asset and does not end with the end of the project. In some cases, assets are transferred to the new owner e.g. the relevant government department, at the closure.

\section{- Record Control and Management}

Project related important documents and records are maintained and managed throughout the project implementation including the procurement process, human resource recruitment and management and contracts and financial records. At the time of closure, the project team ensures that the hard and soft copies of such records are put in place for the storage and necessary security measures are taken. Moreover, its accessibility to the competent authorities is ensured as and when needed.

\section{- $\quad$ Post-Project Activities}

Post-project activities include listing of outstanding actions and assigning responsibilities to individuals or institutions with clear delivery time and reporting. It may include pending outputs, trainings, maintenance or operational matters.

\section{- Future Perspective}

Based on the information provided above, the project team shall recommend how to address the gaps in achievements, residual risk, challenges and opportunities and any other critical matter that could help in improving the practice for the future as part of lessons learned.

The project closure process is as critical as the planning process and is equally time consuming, therefore, it is advised to prepare a checklist at an early stage and assign responsibilities for various tasks to ensure timely completion, discussion and submission of the report.

Table 10 given below is an example of a checklist that depicts standard tasks that a development project closure process manager undertakes and/or assigns to team members.

Development projects engage stakeholders at each step of planning and implementation, hence the decision for initiating closure (Task1) requires the consent of all interested parties. Ideally, the project should have completed all the planned tasks and activities within time and budget, however it seldom happens and therefore any incomplete task or open action item is either completed or closed/cancelled and budget to be revised (Task2).

The next step (Task3) is to close all contracts with staff members, vendors, suppliers and partners including clearing payments and outstanding financial liabilities against contracts.

The project budget review (Task4) is conducted to ensure that fiduciary regulations are complied with and there is no room for audit observations to the contrary.

It is obligatory to conduct staff performance (Task5) and provide separation documentation for them to seek employment elsewhere at the closure of the project unless there is a strong likelihood for some staff to continue as part of the closure process.

Third-party evaluation (Task6) is a good practice in development projects and is encouraged by the senior management, donors and partners. The third party evaluation gives a positive signal for project transparency in both financial and non-financial matters irrespective of the achievement of planed results. All records and documentation to be secured (Task7). The closure process manager can add any other task he/she feels important to complete the process

Table 10. An Example of Checklist for Project Closure Process

\begin{tabular}{|c|c|c|c|}
\hline S. No. & Description of Task & Completion Date & Responsible Person(s) \\
\hline & & $\mathrm{DD} / \mathrm{MM} / \mathrm{YYYY}$ & Project Manager \\
\hline 1 & Obtain stakeholders' consent to initiate Project Closure & By date & $\begin{array}{l}\text { Project Manager/ } \\
\text { Coordinator }\end{array}$ \\
\hline 2 & $\begin{array}{c}\text { Close/complete any open action item on the list of activities and } \\
\text { outputs }\end{array}$ & & $\begin{array}{l}\text { All Team Members lead by } \\
\text { Project Manager }\end{array}$ \\
\hline 3 & Close all contracts & & Procurement Manager \\
\hline 4 & Review and close budget items & & Finance Manager \\
\hline 5 & Conduct Performance Review of staff & & Personnel \\
\hline 6 & Initiate 'Third Party' evaluation & & M\&E Manager \\
\hline 7 & Make arrangement for record storage and security & & Security Officer \\
\hline No. & Continue with the list of relevant tasks. & & Name \\
\hline
\end{tabular}




\section{Conclusions}

In conclusion, the RBM approach, evidently, has certain comparative advantages.

\subsection{Leadership Commitment}

The role of leadership has been mentioned in the earlier sections. It is time to talk about it from the perspective of RBM value system. An engaged and concerned leadership leads by example of practicing RBM at all levels of organizational decision-making process and implementation. Leadership makes its mark on the teams within and outside the organization by demonstrating unconditional commitment and action as stated in the organizational policies, strategy and programme planning.

The RBM stewards at mid and lower management cadres are the most effective links in the leadership chain to ensure adherence to the system by facilitating processes, training and building capacities of all the parties associated with the organization and the programme.

Besides, each and every member of the organization is expected to engage and participate in the learning process and demonstrates RBM application in his/her domain of work; thus all stakeholders as planners, manager, implementers, monitors, evaluators and administrators, are part of the RBM process.

\subsection{Research and Development}

The RBM is essentially based on the 'Theory of Change' and therefore requires baseline information in the outset of the project planning process. The project intervention is designed to raise the socio-economic indicators and to change the status quo in the society. Research, thus, plays a critical role in setting realistic targets according to the priorities and resources available. The change can be swift or subtle. To gauge the change process, the managers have to monitor and evaluate the RBM performance over a period of time.

\subsection{Knowledge Management}

The link between evaluation and knowledge management $(\mathrm{KM})$ is established to ensure that the evaluation findings and recommendations contribute to organizational learning and improving the programming process. Its purpose is to promote and facilitate sharing relevant information, experiences and knowledge for continual improvement. The local experiences add value to the project learning and are used to identify Good Practices.

\subsection{Communication}

Communication is another important aspect and is closely linked with risk management as well as knowledge management through sharing experiences. The RBM works on the concept of 'double loop learning' [47] introduced by Argyris and Schone in 1970s that highlights the criticality of sharing information among stakeholders and receiving feedback. Likewise, communicating risk associated with the intervention and mitigation plans is necessary for safe delivery of the project with wider engagement and participation of stakeholders. Purposeful communication and feedback is RBM's edge in engaging communities to achieve project objectives.

\section{RBM Limitations}

Finally, it is time to reflect upon some limitations and challenges faced in the application of RBM from a practitioner's point of view.

i. There are ideological differences in RBM and other quality concepts. Whereas the RBM focuses on achievement of self-defined multi-level results, most of the quality systems focus on processes and compliance to standards and statutory and regulatory requirement.

ii. The process of planning with RBM techniques is lengthy and complex. It requires time, efforts and total concentration of stakeholders in conducting problem analysis and identifying development needs at local level to reflect in the planning documents. Similarly, the hefty documentation needs a certain level of expertise which may not exist among all the stakeholders.

iii. The language of documentation (mostly being English or French) and local understanding of RBM terminology is another obstacle in compliance to RBM requirements across programme cycle. Translation of its vocabulary in vernacular languages in various countries is a challenge.

iv. Although RBM planning takes into consideration the internal and external risks and assumptions, however, during implementation, it is difficult to systematically monitor these risks and assumptions due to lack of resources. Consequently, at the end of the programme there is hardly any significant information available to measure risk status and mitigation.

v. The progress monitoring and closure reporting is often made within the boundaries of the project and its impact on or integration into the national programme(s) is not demonstrated and verified through clear evidence. It defies the quality criteria set out at the planning stage.

These RBM limitations, if taken into consideration at the time of planning and across project cycle, could help to take us far beyond stated results. 


\section{Appendices}

\section{Appendix 1: List of MDGs}

GOAL 1: Eradicate Extreme Hunger and Poverty

GOAL 2: Achieve Universal Primary Education

GOAL 3: Promote Gender Equity and Empower Women

GOAL 4: Reduce Child Mortality

GOAL 5: Improve Mental Health

GOAL 6: Combat HIV/AIDS, Malaria and Other Diseases

GOAL 7: Ensure Environmental Sustainability

GOAL 8: Develop a Global Partnership for Development

\section{Appendix 2: List of SDGs}

GOAL 1: No Poverty
GOAL 2: Zero Hunger

GOAL 3: Good Health and Well-being

GOAL 4: Quality Education

GOAL 5: Gender Equality

GOAL 6: Clean Water and Sanitation

GOAL 7: Affordable and Clean Energy

GOAL 8: Decent Work and Economic Growth

GOAL 9: Industry, Innovation and Infrastructure

GOAL 10: Reduced Inequality

GOAL 11: Sustainable Cities and Communities

GOAL 12: Responsible Consumption and Production

GOAL 13: Climate Action

GOAL 14: Life Below Water

GOAL 15: Life on Land

GOAL 16: Peace and Justice Strong Institutions

GOAL 17: Partnerships to achieve the Goal

\section{Appendix 3: Quality Management Concepts}

\begin{tabular}{|c|l|}
\hline \multirow{3}{*}{ PDCA } & $\begin{array}{l}\text { The PDCA-Cycle, also called the Deming-Cycle or Shewhart-Cycle, is the classic } \\
\text { problem-solving approach in a LEAN environment. PDCA is used for medium sized problems } \\
\text { and the Act-phase implies that the PDCA-Cycle should start again in the sense of a continuous } \\
\text { improvement process. The Plan-phase should be done very careful and therefore should } \\
\text { consume at least 50\% of the total time of the PDCA. }\end{array}$ \\
\hline A3 & $\begin{array}{l}\text { The A3-Report, developed by Toyota, is an 8-step PDCA that should fit on an A3 sheet of } \\
\text { paper. It is a collaborative and visual tool (graphs should be included). The A3 is also used for } \\
\text { solving medium sized problems, which can be solved in approx. one week or less. A3-Reports } \\
\text { are very common in the LEAN world. }\end{array}$ \\
\hline DMAIC & $\begin{array}{l}\text { The origin of the DMAIC problem solving approach is the Six Sigma world. Basically, it is a } \\
\text { 5-Step PDCA used for large problems where typically a huge amount of data is available. } \\
\text { Therefore DMAIC is often related with statistic tools, but this does not have to be. The } \\
\text { duration of a DMAIC project may exceed more than three months, dependent on the } \\
\text { complexity of the problem and process to be improved. }\end{array}$ \\
\hline 8D/PSP & $\begin{array}{l}\text { The 8D problem solving process, or 8D-Report, is often used in automotive industries. It is an } \\
\text { 8-step PDCA with focus on fast reaction to customer complaints (e.g. a delivered component } \\
\text { or product failed at the customer or in the field). Typically the first three steps should be } \\
\text { accomplished and reported to the customer in three days. Basically PSP is the same thing like } \\
\text { the 8D, but used in aerospace industries. }\end{array}$ \\
\hline
\end{tabular}




\section{REFERENCES}

[1] Theory of Change: A Practical Tool for Action, Results and Learning, Annie E. Casey Foundation, www.organizationalresearch.com 2004, Pp 4-12 \& Online available from https://www.aecf.org/resources/theory-of-ch ange/

[2] Triodos Investment Management Knowledge Centre, Impact investing: in practice, Theory of Change: Steering tool for effective impact investing, Online available from https://www.triodos-im.com/knowledge-centre/theory-of-ch ange

[3] Simplicable Business Guide, 7 Definitions of Quality posted by Anna Mar, March 14, 2013, Online available from https://business.simplicable.com/business/new/7-definitions -of-quality

[4] American Society for Quality (ASQ), Quality Resources Quality Glossary Definition: ISO 9001, Online available from https://asq.org/quality-resources/iso-9001

[5] American Society for Quality (ASQ), Quality Resources Quality Glossary Definition: Continuous Improvement, Online available from https://asq.org/quality-resources/cont inuous-improvement

[6] Principia Cybernetica Web, authored by F. Heylighen, C Joslyn and V. Turchin, Online available from http://pespmc1.vub.ac.be/BOARD.html; $\quad$ Find/Search Principia Cybernetica, ITERATIVE PROCESS - Principia Cybernetica, pespmc1.vub.ac.be/ASC/ITERAT_PROCE.html

[7] Lean Six Sigma Dictionary, Online available from https://www.isixsigma.com/dictionary/deming-cycle-pdca/

[8] Sai Global, NSAI ISO Guide, ISO 9001:2015 For Small Enterprises, published by National Standards Authority of Ireland on 01-01-2015 available in PDF - English, Hardcopy, Preview Online available from https://infostore.saiglobal.co $\mathrm{m} /$ preview/98706475812.pdf?sku=865365_SAIG_NSAI_N SAI 2058210

[9] American Society for Quality, Quality Glossary Definition: ISO 9000 series standards, Online available from https://asq.org/quality-resources/iso-9000

[10] DSQ Inc. Management System Solutions, ISO 9001-2015 Quality Management Assessment Checklist RP-2, issued 9/18/15 revised 5/12/17, Online available from https://dqsus.com/wp-content/uploads/2017/02/RP2-ISO90 01_2015.pdf

[11] American Society for Quality (ASQ), Quality Resources Quality Glossary Definition: Total quality management, Online available from https://asq.org/quality-resources/total -quality-management

[12] European Framework for Quality Management (efqm) Online available from https://www.efqm.org/index.php/efq m-model

[13] European Framework for Quality Management (efqm) Online available from https://www.efqm.org/index.php/efq m-model/

[14] UNESCO Results-Based Programming, Management and Monitoring (RBM) Guiding Principles, UNESCO Paris, Bureau of Strategic Planning, January 2008, Online available

fromhttp://old.unesco.kz/publications/ed/RBM_guide_en.p df

[15] Wikipedia - The Free Encyclopedia, Results-based Management, Online available from https://en.wikipedia.or g/wiki/Results-based_management \& https://en.wikipedia.o rg/wiki/Results-based_management\#Usage_of_RBM

[16] Kusek, J.Z. and Rist, R. C, Ten steps to a results- based monitoring and evaluation system, The International Bank for Reconstruction and Development / The World Bank, Washington, 2004, Online available from http://www.oecd.org/dataoecd/23/27/35281194.pdf

[17] Kusek, J.Z. and Rist, R. C, Ten steps to a results- based monitoring and evaluation system, The International Bank for Reconstruction and Development / The World Bank, Washington, http://www.oecd.org/dataoecd/23/27/35281194.pdf

[18] Results-based management principles and standards, UNFPA, New York, USA, ISBN: 978-1-61800-035-4, 2019

[19] Glossary of Evaluation Terms, Compiled and Edited by Thomas A. Lifvendahl, Ed. D. Term Evaluation P. 5, Online available from http://drtomlifvendahl.com/Glossary\%20of $\% 20$ Evaluation $\% 20$ Terms.pdf

[20] Results based management - Wikipedia, the free encyclopedia; Online available from http://en.wikipedia.org /wiki/Results-based management

[21] Designing IAEA Technical Cooperation Projects using the Logical Framework - Approach - A Quick Reference Guide, Online available from https://www.iaea.org/sites/default/fil es/documents/tc/LFA-ref.pdf

[22] Designing IAEA Technical Cooperation Projects using the Logical Framework - Approach -A Quick Reference Guide, Online available from https://www.iaea.org/sites/default/fil es/documents/tc/LFA-ref.pdf

[23] Global Conflict Sensitivity Community Hub (CSC-Hub) Online available from https://conflictsensitivity.org/conflict -sensitivity/do-no-harm-local-capacities-for-peace-project/

[24] BPlans Business Planning Guide, Web Article on How to Do a SWOT Analysis for Better Strategic Planning by Tim Berry, Online available from https://articles.bplans.com/ho w-to-perform-swot-analysis/

[25] Society for Risk Analysis (SRA) Glossary, Online available from https://www.sra.org/resources

[26] Bright Hub PM, Web Article Stakeholder Analysis Example for Project Management 5 Oct. 2008, Online available from https://www.brighthubpm.com/monitoring-projects/10426example-of-stakeholder-analysis/

[27] Smith, L. W. (2000). Stakeholder analysis: a pivotal practice of successful projects. Paper presented at Project Management Institute Annual Seminars \& Symposium, Houston, TX. Newtown Square, PA: Project Management Institute, Online available from https:/www.pmi.org/learni ng/library/stakeholder-analysis-pivotal-practice-projects- 89 
05

[28] https://www.pmi.org/learning/library/stakeholder-analysispivotal-practice-projects- 8905

[29] https://innovationforsocialchange.org/wp-content/uploads/2 014/09/stakeholder-analysis-template.jpg

[30] Kusek, J.Z. and Rist, R. C, Ten steps to a results- based monitoring and evaluation system, The International Bank for Reconstruction and Development/The World Bank, Washington, 2004; http://www.oecd.org/dataoecd/23/27/35 281194.pdf

[31] https://www.nap.edu/read/25056/chapter/4

[32] Marc Kuhn, Clemens W Baumann; Triangulation in industrial market research -development of a mixed-methods-approach for market forecasts, AMS World Marketing Congress, 2011, Reims, France, Online available from

https://www.researchgate.net/publication/274067942_TRIA NGULATION IN INDUSTRIAL MARKET RESEARC H_DEVELOPMENT_OF_A_MIX̄ED-METHODS-APPR OACH_FOR_MARKET_FORECASTS/stats

[33] UN Habitat / Swiss Federal Institute of Aquatic Science and Technology (Eawag) Clues Guideline D8.1, Online available fromhttps://www.eawag.ch/fileadmin/Domain1/A bteilungen/sandec/schwerpunkte/sesp/CLUES/Toolbox/t8/ D8_1_Problem_Tree_Analysis.pdf

[34] Duke Okes, Root Cause Analysis, ASQ Quality Press, Milwaukee, Wisconsin, 2009

[35] UN Habitat / Swiss Federal Institute of Aquatic Science and Technology (Eawag) Clues Guideline D8.1, Online available fromhttps://www.eawag.ch/fileadmin/Domain1/A bteilungen/sandec/schwerpunkte/sesp/CLUES/Toolbox/t8/ D8_1_Problem_Tree_Analysis.pdf

[36] F. Aneani, R. Adu-Acheampong, O. Sakyi-Dawson; Exploring Opportunities for Enhancing Innovation in Agriculture, Sustainable Agriculture Research; Vol. 7, No. 1; 2018 ISSN 1927-050X E-ISSN 1927-0518 Published by Canadian Center of Science and Education

[37] Designing IAEA Technical Cooperation Projects using the Logical Framework - Approach - A Quick Reference Guide, Online available from https://www.iaea.org/sites/default/fil
es/documents/tc/LFA-ref.pdf

[38] IUCN Guide, Chapter 4 Project Implementation and Monitoring Version 3, 29 July 2014, Online available from https://www.iucn.org/sites/dev/files/import/downloads/4 i mplementation_and_monitoring_final_29_07_14.pdf

[39] CIDA's Practical Guide to Planning Large Development Projects by Greg Armstrong 25 January 2010, A Results Approach to Developing the Implementation Plan: A Guide for CIDA Partners and Implementing Agencies, Online available from https://results-based-management.blogspot.com/2010/02/ci das-practical-guide-to-planning-large.html

[40] CIDA's Practical Guide to Planning Large Development Projects by Greg Armstrong 25 January 2010, A Results Approach to Developing the Implementation Plan: A Guide for CIDA Partners and Implementing Agencies, Online available from https://results-based-management.blogspot.com/2010/02/ci das-practical-guide-to-planning-large.html

[41] Jody Zall Kusek \& Ray C. Rist, Ten Steps to a Results-Based Monitoring and Evaluation System, Operations Evaluation Department, The World Bank, 2004

[42] IUCN Guide, Chapter 4 Project Implementation and Monitoring Version 3, 29 July 2014, Online available from https://www.iucn.org/sites/dev/files/import/downloads/4_i mplementation_and_monitoring_final_29_07_14.pdfk

[43] Michael Quinn Patton, Utilization Focused Evaluation, 4th edition, Sage Publications, Inc. California USA, 2008

[44] Michael Quinn Patton, Utilization Focused Evaluation, 4th edition, Sage Publications, Inc. California USA, 2008

[45] IUCN Guide, Chapter 4 Project Implementation and Monitoring Version 3, 29 July 2014, Online available from https://www.iucn.org/sites/dev/files/import/downloads/4_i mplementation_and_monitoring_final_29_07_14.pdf

[46] Web Knowledge Source Flylib.com, Completing Administrative Closure, Online available from https://flylib.com/books/en/4.273.1.102/1/

[47] C. Argyris, Double Loop Learning Theory, Online available from http://www.instructionaldesign.org/theories/double-loop/ 